\title{
Financial Integration and Economic Growth: Empirical Evidence from the Republic of Georgia
}

\author{
Zaur Phutkaradze ${ }^{1}$, Asie Tsintsadze ${ }^{2}$, Beka Phutkaradze $^{3}$
}

\begin{abstract}
Despite the vast amount of research studies, there is no clear and unambiguous opinion among economists on how the international financial integration (IFI) affects economic growth. This paper attempts to investigate the relationship between financial integration and economic growth in the Republic of Georgia. The study employs a log-linear equation for economic growth and covers the time-series data over the period of 1995-2016. OLS estimations do not provide statistically significant evidence for IFI-growth relationship. However, although the significance of this linkage is not apparent, it is important to highlight the main tendency - financial integration plays a positive role when the country has a relatively stable currency and negative role during the period of significant currency fluctuations. Outcomes of the study are consistent with our theory and support prior researches in this area.
\end{abstract}

Keywords: Financial integration; economic growth; empirical model

\section{Introduction}

Over the last decades, international financial integration and its impact on socioeconomic environment has been the subject of consideration of leading economists in the world. Special attention has been devoted to the example of developing countries. According to one of the definitions, international financial integration, or financial openness $^{1}$, is the movement of direct investments, foreign capital and commercial transactions between domestic and foreign markets. This is the integration of the local financial system with international financial markets and institutions.

Despite the vast amount of research studies, there is no clear and unambiguous opinion among economists on how the international financial integration affects economic growth of a country. Globalists talk about the economic and technical achievements that accompany this process. They declare that financial integration increases domestic stock market liquidity and improves the provision of financial services through sophistication of banking system [Obstfeld, 1994; Quinn, 1997]. Kose et. al [2009] in their study conducted by International Monetary Fund (IMF) discuss the

${ }^{1}$ In this study, financial integration, financial globalization, financial openness and capital account liberalization are treated as synonyms.

${ }^{1}$ Academician at Georgian Academy of Agricultural Sciences; Professor at Batumi State Maritime Academy, The Faculty of Business and Management, Batumi, Georgia.

2Professor at Batumi Shota Rustaveli State University, The Faculty of Economics and Business, Batumi, Georgia.

${ }^{3} \mathrm{PhD}$ student at Batumi Shota Rustaveli State University, The Faculty of Economics and Business, Tbilisi, Georgia. 
benefits of technology and management transfers during international financial integration. On the other hand, anti-globalists, mainly, claim that the integration into global financial markets is associated with respective risks and can lead to various severe crises. For example, currency crises are vastly associated with sharp capital flow reversals [Beck et. al., 2013]. Joseph Stiglitz, a Nobel Prize winner in economics, argues that some type of capital flows and excessive borrowings may be potentially hazardous because of inefficient resource-allocation and asymmetric information in various countries [Stiglitz, 2000]. Other economists suggest that in order to gain positive results from IFI the country must satisfy some key prerequisites, which, mainly, concern to institutional quality and sound financial system [McKinnon, 1991; Ju and Wei, 2007]. There are also empirical studies, which did not find any significant relationship between financial integration and growth [Grilli and Milesi-Ferretti, 1995; Rodrik, 1998; Edison et. al., 2004]. Finally, some economists derived mixed empirical results as well [Kraay, 1998; Edwards, 2001; Durham, 2004].

As it stands, the relationship between financial integration and economic development is very complex and sensitive process, depending on the studied countries, their economic, political, legal, social, geographical and other specifications. This can be one of the explanations on such diverse results on integration-growth nexus across different counties and regions. In light of abovementioned, it is interesting to determine this relationship across time in the Republic of Georgia. It should be noted, that Georgia has begun the process of integration into global financial markets since more than two decades already and its economy and banking sector has been growing steadily throughout this period. The country has undergone through several recession periods after 2008 Russian-Georgian war and significant currency devaluation in years 20152016. Therefore, it would be particularly interesting to understand whether a financial integration promotes economic development in Georgia. We employ Ordinary Least of Squares (OLS) method to test the time-series data for the period of 1995-2016.

The remainder of this paper has following structure: The subsequent section overviews main concepts and literature on the relationship between international financial integration and economic growth. Section 3 is dedicated to the empirical model and its variables' specifications. Section 4 interprets the empirical results and describes possible reasons of such outcomes. The concluding remarks are presented in the last section.

\section{Literature Review}

Maurice Obstfeld [1994] was one of the earlier economists, who conducted an influential study on relationship between global financial integration and economic growth. His main conceptual framework was based on benefits of global diversification and risk-sharing opportunities through financial integration. According to the paper, most countries obtain great welfare gains from financial globalization, because international financial integration allows shifting of world portfolio from less-profitable countries to high-profitable ones, compensating respective risks. This hypothesis is consistent with conventional belief about financial openness theory. Financial globalization gives opportunity to increase investments in developing economies, 
offering investors a higher return on investment (ROI), compared to industrial countries [Lucas, 1990]. Financial diversification reduces the risk-free rate in the developing economies, which means that the cost of capital is diminishing as well, while the overall and ultimate impact on economic growth is positive. Decrease in the cost of capital through efficient risk-allocation stimulates economic growth [Badri and Sheshgelani, 2016].

Some remarkable studies outline that apart from direct channels, through which financial openness affects economic growth, there are indirect impact-channels as well, such as: efficient capital allocation, enhanced production specialization, transfer of management experience and corporate governance etc. [Obstfeld, 1994]. The research papers on direct impact-channels seek for a positive relationship between financial integration and economic development. On the other hand, the papers on indirect channels state that positive growth effects are only collateral and can be reached through healthier financial system, institutional quality and efficient macroeconomic policies [Bekaert et al., 2005]. Anti-globalists actively criticize direct positive IFI-growth nexus and question the benefits from indirect impact-channels as well. They argue that the benefits from indirect impact-channels are rather intangible and undocumented, while the negative outcomes from financial integration are colossal and real [Obstfeld, 2008]. Klein and Olivei [2000] and Levine [2001] advocate that the financial integration may improve a country's financial sector by importing financial services from more experienced countries and consequently support economic growth.

Numerous authors claim that capital flows depend on the advancement of a country's financial system and other important macroeconomic factors. Therefore, potential benefits from financial openness depend on the soundness of financial sector and these macroeconomic variables, especially for the developing and emerging economies. These prerequisites that are necessary to reap positive IFI-growth effects are commonly referred as "threshold" conditions [Kose et al., 2010]. In general, these "threshold" factors are country characteristics, such as: the degree of trade and capital flow openness, wealth distribution, the level of income and financial development, institutional quality and efficiency of macroeconomic policies. For instance, Aoki et al. [2006] conclude that capital account liberalization is not inevitably favorable for a country when its financial industry is weak and immature. Prasad et al. [2006] note in their study that even though an international capital flows have increased significantly over recent decades, advocating a more global financial world, the allocation of flows becomes more inefficient compared to economic theory expectations. Lucas [1990] argued that international flows from capital-reach to capital-poor economies were much smaller than the levels expected by the standard theory. Prasad et al. [2006] also stated that the paradox has deepened over time with capital flowing from developing to industrial economies, especially since the beginning of $20^{\text {th }}$ century. The research states that the pattern is actually opposing, meaning that medium and high growth economies transfer substantial amounts of capital while low-growth economies obtain in huge amounts. This fact is referred as a "Lucas Paradox" among economists. The authors, however, admit that the foreign direct investment generally follow the predictions of the theory [Prasad et. al., 2006]. 
Boyd and Smith [1992] indicate that financial liberalization in countries with weak legal system and undeveloped financial institutions may actually stimulate a capital outflow to industrial countries, where the institutional quality is much higher. Another criticized study was conducted by Krugman [1993], which pointed out that financial integration cannot have a major driving influence on economic growth. The author argued that the IFI-growth linkage has no solid grounds in economic theory either. Joseph Stiglitz, nowadays one of the most influential economists, closely linked amplified occurrence of currency crises with financial openness [Stiglitz, 2000]. According to his analysis, the liberalization of capital accounts in several East Asian countries was the most important reason that lead to the currency crisis in Asian during late 90s. John Williamson, the World Bank's former Chief Economist, argued that the only factor that explains the reasons of Asian currency crisis is the capital account liberalization [Wang, 2006]. Remarkably, all the currency (and financial) crisis that occurred in Asia, Russia and Latin America had very similar prerequisites: the liberalization of capital accounts and cross-border flows shortly prior to the beginning of the crisis. For example, several years before 1998, Malaysia unrestricted international transactions of its domestic currency in offshore markets. Portfolio capital flows (both inward and outward) were liberalized. The inflow of FDI was stimulated in Malaysia, while there were no considerable restrictions on FDI outflows [Wang, 2006]. Similarly, prior to currency crisis in Russia during late 90s, the government implemented relaxation policy on foreign portfolio investments in 1997. The portfolio flows in the Russian market during the first quarter of 1997 exceeded the amount for the whole 1996 by more than three times [Pinto and Ulatov, 2010].

As for the empirical studies, different methods were applied to investigate the relationship between financial integration and economic growth. For instance, Edison et. al. [2002] utilized variety statistical techniques to explore the IFI-growth relationship and also to evaluate whether this nexus depends on the level of financial, economic, legal system developments and other macroeconomic aspects. The authors used various measures of IFI using ordinary least squares (OLS) and Generalized-Method-ofMoments (GMM) estimators. The study covered 57 countries across the period 19802000 for the cross-sectional OLS method and 1976-2000 for the dynamic panel GMM method. The outcomes of the study revealed that the international financial integration does not stimulate economic development. Moreover, the authors concluded the same results even when controlling for specific political, institutional, economic and financial policies [Edison et. al., 2002].

Alfaro et. al. [2004] concentrated their study on the influence of foreign direct investment on economic development. The research concludes that the deficiency of financial development can limit the country's capability to efficiently use potential spillover benefits that are accompanying FDI inflows. Kose et. al. [2008] also underlined the significance of FDI. The authors state that, taking into account the degree of financial development in non-industrialized countries, the benefits of financial integration are most apparent when they receive capital inflows through FDI or portfolio equity investments.

Klein [2005] applied the cross-section OLS and IV statistical methods to investigate the integration-growth association. The research covered 71 countries, while the timeframe of 1984-1995 was utilized. The author concluded that a financial 
integration is positively correlated with economic growth during medium levels of institutional development.

Bonfiglioli [2008] conducted macro research on association of financial integration with total productivity growth. The empirical study covered the period of 1975-1999, using cross-country data. The results revealed a positive direct impact of financial integration on productivity growth.

The research study, conducted by European Bank for Reconstruction and Development (EBRD) in year 2010, attempted to understand whether integrationgrowth relationship is different in emerging Europe. The study used industry-level data and analyzed several aspects that may explain integration-growth nexus, in particular: the trade integration, institutional quality, political integration, financial development and financial integration itself. The research found out that the positive consequences of financial integration are most apparent for the nations that are politically closest to the European Union, suggesting that the political integration can significantly surge the benefits of financial integration [Friedrich et.al., 2010].

Mahajan and Verma [2015] studied association between financial openness and economic development in India. Their research covered the period of 1981-2011. In order to investigate the integration-growth relationship, the authors employed cointegration model and Vector Error Correction Model (VECM). The research paper observes positive outcomes, which mean that more financial openness stimulates economic growth in India.

Badri and Sheshgelani [2016] studied the relationship between financial development, financial integration and economic growth. The research was conducted for 24 OIC countries applying panel data method. The analyzed timeframe included 2005-2013 years. According to the results of the study, financial development had positive impact on economic prosperity in selected countries, while the financial integration was negatively correlated with growth.

Furthermore, certain economists could not find any significant relationship between financial integration and economic development [Alesina et. al., 1994; Grilli and Milesi-Ferretti, 1995; Rodrik, 1998, Edison et. al., 2004]. According to study Rodrik and Subramanian [2008], it is progressively hard to find the benefits of financial integration on economic development, even when the financial crises are set apart. The authors stated that financial integration has not generated higher growth or reduced volatility in emerging markets. Moreover, they label arguments for financial globalization as speculative and unconvincing [Rodrik and Subramanian, 2008].

Additionally, some studies conducted on examination of IFI-growth relationship derived mixed outcomes. For example, Arteta et al. [2001] analyzed the impact of capital account liberalization on economic development for 61 countries across 1973-1992 periods. The results revealed that financial integration can as likely to help as to hurt economic growth. Similarly, mixed effects were exposed in number of other research papers [Kraay, 1998; Edwards, 2001; Durham, 2004].

As it can be observed from the literature above, there is no clear and unambiguous answer on whether there is positive correlation between financial globalization and economic prosperity. The conducted theoretical and empirical studies appear to have mixed results, depending on the specifications of particular research. 


\section{Empirical Model}

Our empirical strategy is to elucidate the tendency in economic growth and its changes across time in the Republic of Georgia. For this reason, it should be tested if tendencies in economic development are connected with trends in financial integration. Therefore, in our analyses we have to ensure that our estimates of Georgia's economic deepening capture the influence of the exogenous component of financial integration.

The general equation to be estimated is:

$\mathrm{Y} t=\alpha+\mathrm{X} t \beta+\varepsilon t$

where $y t$ is a dependent variable, $x t$ is a vector of independent variables, $\varepsilon t$ is error term, and $t$ indexes time measured in years. We treat all terms as exogenous. Since in most of the cases time-series data doesn't suffer for heteroskedasticity (it is mostly a crosscountry phenomena), we don't incorporate analysis for heteroskedasticity in our model.

Our empirical model aims to analyze the economic growth of Georgia, covering 22 time periods. The commonly accepted method is to employ data at an annual basis for the estimation purposes. Using annual data in our analyses has a weakness, because it disregards the probability that annual data might not represent long-run equilibrium values in any given year. The reason for this is the slow modification to fluctuations in the parameters. In order to avoid this issue we need to design a model that will allow the possibility of partial adjustment. We derive a log-linear equation for economic development. ${ }^{2}$ Hence, an empirical formula has the following illustration:

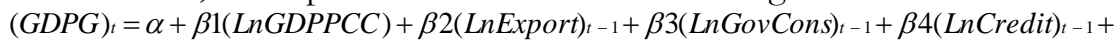

$+\beta 5(\text { LnCapFlow })_{t-1}+\beta 6(\text { LnDeflator })_{t-1}+\varepsilon t$

Where GDPG stands for gross domestic product growth; GDPPCC is a gross domestic product per capita based on constant 2010 U.S. dollar prices; Export is a total value of exported goods and services; GovCons represents general government final consumption expenditures; Credit is a domestic credit to private sector by banking sector; CapFlow is a gross capital flows, represents the proxy for financial integration; Deflator represents an inflation parameter; $₫$ is error term. All explanatory variables [except GDPPCC] are expressed as one-period lagged values.

\section{Data, Measurement and Sources}

In our research of financial integration and economic growth, we estimate standard growth equation using a dataset over the period of 1995-2016. Data are obtained from various sources. Financial integration measure is obtained and derived from National Bank of Georgia (NBG) sources. GDP growth, GDP per capita, private credit, government spending, exports and inflation are obtained from World Development Indicators (WDI) database.

Economic growth is calculated by the real GDP growth rate. Indicators that we employ as control terms that may explain economic growth include the following:

2Some observations, for example on financial development may not represent long-run equilibrium values in any given year, because of slow adjustment to changes in other variables. Financial development indicators that are asset based are likely to display considerable persistence: the size of the banking system in any given year is history dependent. To allow for the possibility of partial adjustment, we specify a log-linear equation. 
financial integration, GDP per capita, exports, government spending, inflation and private credit.

According to one of the definitions, financial integration is a phenomenon in which financial markets of various countries are closely integrated to each other, forming global financial markets. The degree and form of financial integration differs from country to country. Unlike developing economies, developed countries are expected to have relatively high financial integration parameter. The form of financial integration may include various interrelations between financial institutions, such as: sharing of know-how and best practices, technologies, cross-border capital flows, participation in foreign financial markets etc. The economists suggest various ways of measuring the level of financial integration of a country. For example, some theories are based on de jure measurements of financial integration, which are based on dummy variables. One of the most well-known and commonly accepted de jure proxies for financial integration is the Chinn-Ito index (KAOPEN). This index initially was adopted by Chinn and Ito in 2006. KAOPEN is stated in the IMF's Annual Report on Exchange Arrangements and Exchange Restrictions (AREAER). The index is constructed via binary dummy variables that categorize the restrictions on cross-border financial flows. Unlike de jure parameters of financial integration, which usually capture a degree at which a country enforces policy constraints on cross-border capital transactions, de facto measures are more quantitybased and capture actual level of global financial integration of a country. Perhaps there are two most widely used de facto measures of financial integration. The first (TOTAL) index proposed by Lane and Milesi-Ferretti [2007]. The authors of this index suggest that one of the ways to assess a country's level of international financial integration is to understand the movements in external assets and liabilities, so-called international investment positions (IIP). Consequently, the TOTAL index is derived as a country's total assets plus total liabilities as a percentage of GDP. The second approach attempts to use apparent phenomena of augmented capital mobility, such as the gross capital flows [Quinn et al., 2011]. If we take into consideration the growing trend of international capital flows across the globe during the recent decades, this proposition sounds particularly viable. For instance, the capital flow approach was one of the ways to measure financial integration in the study conducted by Asian Development Bank [Estrada et al., 2015]. Furthermore, various traditional literature on financial globalization actively advocate a capital flow index as a proxy for measuring the degree of financial globalization. In our analysis we also use annual data on gross capital flows, as a corresponding measure of financial integration of Georgia. In order to calculate this indicator, we employ financial account data from the balance of payments of Georgia (source National Bank of Georgia, NBG). In particular, we derive financial integration parameter by summing year-end absolute values of inflows and outflows (assets and liabilities) of direct investment (DI), portfolio investment (PI), financial derivatives (FD), and other investment (OI). Then we express these data as percentages of respective yearly GDP. The reason why we use absolute values of flows is that the gross flows are preferred over net, because they provide more accurate picture of integration [Estrada et al., 2015]. Majority of research papers conducted on IFI-growth interconnection conclude positive results between these two variables. The economists name several important factors, through which non-restricted cross-border capital flows facilitate 
economic growth: risk-diversification, capital allocation, transfer of technology and know-how, enhanced competition level, improved functioning of financial industry etc. [Obstfeld, 1994; Acemoglu and Zilibotti, 1997; Klein and Olivei, 2000; Levin, 2001]. Joseph Stiglitz in his study [Stiglitz, 2000] also highlights the importance of cross-border capital transactions for economic growth, but he admits that the full capital account liberalization is harmful and respective regulations are essential in order to reap positive results. For instance, a country can benefit from long term foreign direct investments, which transfer technological achievements, managerial experience and are oriented on productivity growth. On the other hand, there is a high risk that short term capital flows can be damaging, especially for developing countries that have less sound financial sector. The author claims that short-term capital flow movements can result in small shocking effects on a country's economy, because the risks outweigh the benefits from short-term transactions [Stiglitz, 2000].

In this paper we expect capital flow parameter to have a positive impact on economic growth, because according to the balance of payments of Georgia, on average the yearly FDI comprise more than $50 \%$ of total capital flows of Georgia. Such high FDI flows and accompanying benefits should indeed positively correlate with economic development. Nevertheless, some historical facts suggest that the international financial integration can have negative consequences during currency crisis and general economic stagnation. There are several such real case scenarios, when financial openness had negative influence on a regional level during Latin America, Asian and Russian currency crises in 90s. It is important to note that Georgia experienced quiet severe currency fluctuations during 2015-2016 years, when the exchange rate between local currency (GEL) and US dollars has depreciated more than $40 \%$. This fact could negatively influence IFI-growth relationship. Therefore, we decided to test this hypothesis and consequently divided our analysis into two sample periods: 1) full sample size that covers period of 1995-2016, which entails two years of currency devaluation in 2015-2016; 2) sub-sample size, covering a time-frame of 1995-2014, which does not incorporate the periods of currency devaluation. According to our estimations and relevant literature review, we expect to have a non-positive linkage for the full sample and a positive relationship for the sub-sample sizes.

We also include initial per capita real income on the right-hand side because higher incomes are likely to correlate with more economic activity. This variable is incorporated in the empirical model to capture the convergence effect across countries. The yearly figures on real GDP per capita are collected from the World Development Indicators (WDI). We continue to treat GDP per capita as exogenous. The expected sign of the parameter of the initial level of economic development variable is positive.

The next variable used in our research as a determinant of economic growth is exports. As a measure of exports, we use the exports of goods and services in relation to GDP. According to traditional Keynesian theory, export is one of the main aspects that can promote economic progression. Empirical researches conducted by Vohra in 2001 and Marin in 1992 have confirmed, that export positively impacts economic growth. The expected sign of the coefficient is positive.

Numerous studies [King and Levine, 1993; Levine and Zervos, 1998; Beck and Levine, 2004] have proved that better developed financial system positively shapes 
economic growth. We employ banking sector development, particularly private credit issued by banks as a representative variable of the financial development. The variable is presented as percentage of GDP. The figures are gathered from the WDI dataset. It is commonly established among economists that the private credit variable is a vital banking development pointer, for the reason that it illustrates the level to which new firms have opportunities to get bank finance. According to Rajan and Zingales [2003], private credit measures the easiness to obtain finance for a sound project. Levine et al. [2000] states that this variable separates the credit issued to the private sector, as opposed to credit issued to governments, government agencies and public enterprises. Furthermore, it does not count credit provided by the central bank. As a consequence, we interpret higher points of this parameter as a demonstration of increased credit accessibility and overall financial development. This is our preferred measure of financial progression, because it is the most straightforward measure of financial availability to the private sector. In general, economists expect positive impact of financial development on economic growth. However, there are numerous research papers that conclude different outcomes, especially for the developing and transition economies, where the financial institutions are still at the early stages of development. Djalilov and Piesse [2011] conducted study on financial development-growth nexus for the 27 former Soviet republics and Eastern European countries. Their results show that credit provided to private sector has no significant effect on economic progress. Additionally, two other variables of financial development were used: 1) financial index proposed by EBRD, which consists from different financial arguments; 2) the difference between interest rates on credit and deposit, which is a proxy for competition level in banking industry. These two variables of financial development appeared to have negative influence on growth. The authors explain such results by less developed institutional degree of financial sector in these countries. They admit that least developed financial institutions in these countries hamper economic development, as the financial resource-allocation process is not conducted on the bases of economic efficiency. Moreover, such important aspects as asymmetric information and high transaction costs are typical for developing countries, which negatively affect financial transactions and growth [Djalilov and Piesse, 2011]. Levine and Zervos [1998] also highlight the importance of institutional development. The research suggests that not necessarily the degree of savings and investments lead to economic progression, but rather the more efficient resource allocation and productivity, which are capabilities of institutionally strong economies. Halil Aric [2014] analyzed the relationship between financial development and economic growth in European Union for the period of 2004-2012. The domestic credit to private sector as a \% of GDP was employed as a proxy for financial development variable. The paper revealed negative finance-growth relationship. The author explains this by fact that the credit provided to private sector is not utilized in growth-oriented areas. In case of Georgia, the country's financial sector has been developing steadily and significantly throughout the last decade (often exceeding $20 \%$ growth). However, the allocation of financial resources is not efficient, because the entire growth of Georgian banking sector is largely due to extremely high number of private/household borrowers from commercial banks. According to Financial Access Survey (FAS) that is proposed on the yearly bases by International Monetary Fund (IMF), the number of borrowers in Georgia per 1000 adults was 723 in year 2016. Such high level of commercial banks' lending automatically questions 
the efficient allocation of financial resources and this might indicate on high risk that most of such borrowings are not growth-oriented. Therefore, we expect that financial development should have negative impact on economic growth of Georgia.

One more control term in our hypothesis formula is government expenditures. The government spending plays an imperative role in establishment of sufficient atmosphere for development of private sector. Yet, numerous empirical and theoretical papers suggest negative interrelation between large government consumption and financial system development in a country. Generally, it is established among economists that investments' efficiency declines during excessive government expenditures, because investment decisions are influenced by societal and political aspects [Webb et. al., 2002]. The government consumption is especially important in case of Georgia, because government played an active role in promoting GDP growth of the country. For instance, after "Rose Revolution" in 2003 and change of the government of the country, one of the priorities of new government was social and healthcare system. The government provided full or partial funding for health insurance of big part of the population. Another example could be a partnership fund, which was formed by Georgian officials in 2011. The fund's main objective is to provide finance to sound projects and execute exit option once the business becomes sustainable. We measure government expenditure as a ratio of general government expenditures to GDP. We expect negative link between government expenditures and economic growth.

The last control variable is inflation. Inflation is widely utilized among economists as an important determinant of economic growth. In general, it is agreed that inflation has negative correlation to economic development as it may adversely affect those sections of the population whose earnings are not indexed to prices (usually poor and below average population segment). Additionally, inflation may alter relative prices, lead to exchange rate fluctuations and create general instability in a country [Prasanna and Gopakumar, 2011]. Nevertheless, various theoretical and empirical studies show that the inflation-economic growth nexus may vary due to various reasons. For instance, in the short run, the linkage between inflation and growth is usually positive, while on the long run, there is a negative and significant correlation. Another interesting point relates to the country categories and a threshold levels of inflation. Khan and Senhadji [2001] investigated the inflation-growth correlation for developing and industrial countries separately. The authors found out that the impact of inflation on economic development differs across these two country segments. In particular, their results disclose the presence of a threshold beyond which inflation adversely influences growth. Inflation rates, which are below the threshold levels of inflation, have no or even positive consequence on economic development. On the other hand, inflation levels beyond the threshold play negative role on inflation-growth relationship. The authors proposed that the threshold boundary is lower for industrialized economies compared to developing countries. The respective threshold levels appeared to be 1-3 and 11-12 percent for industrial and developing economies. Numerous studies concluded that on average the threshold is about $8-12 \%$, beyond which the inflation has significant and negative impact on growth, while below this threshold there is no negative influence [Mubarik, 2005; Khan and Senhadji, 2001; Sarel, 1995]. In our regression model we expect inflation variable to have a positive sign, because Georgia is still a developing country and its inflation levels are usually below 10\% during analyzed time-frame. 
Table I presents the descriptive statistics for all the variables used in the regression. Given table shows the means, standard deviation, and minimum and maximum values of each parameter.

Table I: Descriptive Statistics: Economic development dataset of the Republic of Georgia, annual data 1995-2016

\begin{tabular}{|c|c|c|c|c|c|}
\hline \multicolumn{6}{|c|}{ Descriptive Statistics } \\
\hline Variable & Obs & Mean & Std. Dev. Min & Min & Max \\
\hline GDPG & 22 & 5.585373 & 3.900385 & -3.650101 & 12.344 \\
GDPPCC & 22 & 2389.714 & 1005.454 & 1010.251 & 4083.998 \\
Export & 22 & 30.52406 & 9.334406 & 13.32629 & 44.73796 \\
GovCons & 22 & 15.16971 & 5.315925 & 7.698666 & 25.87842 \\
Credit & 22 & 21.91759 & 16.84243 & 3.30373 & 56.80942 \\
CapFlow & 22 & 0.1561886 & .0734297 & .0547132 & 0.2930368 \\
Deflator & 22 & 14.66224 & 34.16555 & -2.136432 & 162.7251 \\
\hline
\end{tabular}

Source: Own calculations via STATA

As indicated in Table I, all the indicators display substantial variations. For example, Private Credit, GDP growth, GDP per capita and Deflator measures demonstrate broad variations between maximum and minimum values, as well as the range of standard deviation measures. The negative values in GDP growth and Deflator variables took place in year 2009, which are linked to recession period in Georgia due to global financial crisis and Russian-Georgian war in 2008. The lowest GDP per capita level was 1010.251 in 1995, when Georgia had very difficult socio-economic condition, recovering after collapse of Soviet Union.

\section{Non-Stationarity and Transformation of the Time Series Data}

In order to conduct a valid statistical inference, we must make key assumption in time-series analysis. We have to assume that our time-series model is covariance-stationary. A stationary process is a stochastic process whose joint probability distribution does not change when shifted in time. Thus, properties such as the mean and variance, if they are present, also do not change over time and do not follow any trends. Stationarity is used as a tool in time series analysis, where the raw data is often transformed to become stationary. Using non-stationary time series data in economic models produces untrustworthy and spurious consequences and leads to poor understanding and forecasting. In particular, $\beta$ will be biased, and any hypothesis testing will be invalid.

We can check if our initial data is stationary by looking at a plot of the time series (see Graphs 1-7). If the graph shows almost the same mean and variance through time without significant seasonality, then we can assume that the time series is covariance-stationary. As it is visible from the plots in Graphs 1-7, some of the variables are non-stationary. The time series appear to grow (or decline) steadily through time and as a result have a mean that is non-constant, which entail that they are non-stationary. We can observe from the graphs that the time series of Government Consumption, Export, Credit, Capital Flow and GDP per capita variables clearly show the mean increasing as the time passes. All these variables demonstrate growth of mean values 
over time. Thus, these variables are not covariance-stationary. Other variables in the model (GDP growth and Deflator) seem to illustrate relatively stable mean values with periods of steady increase and decline over different pieces of the time period.
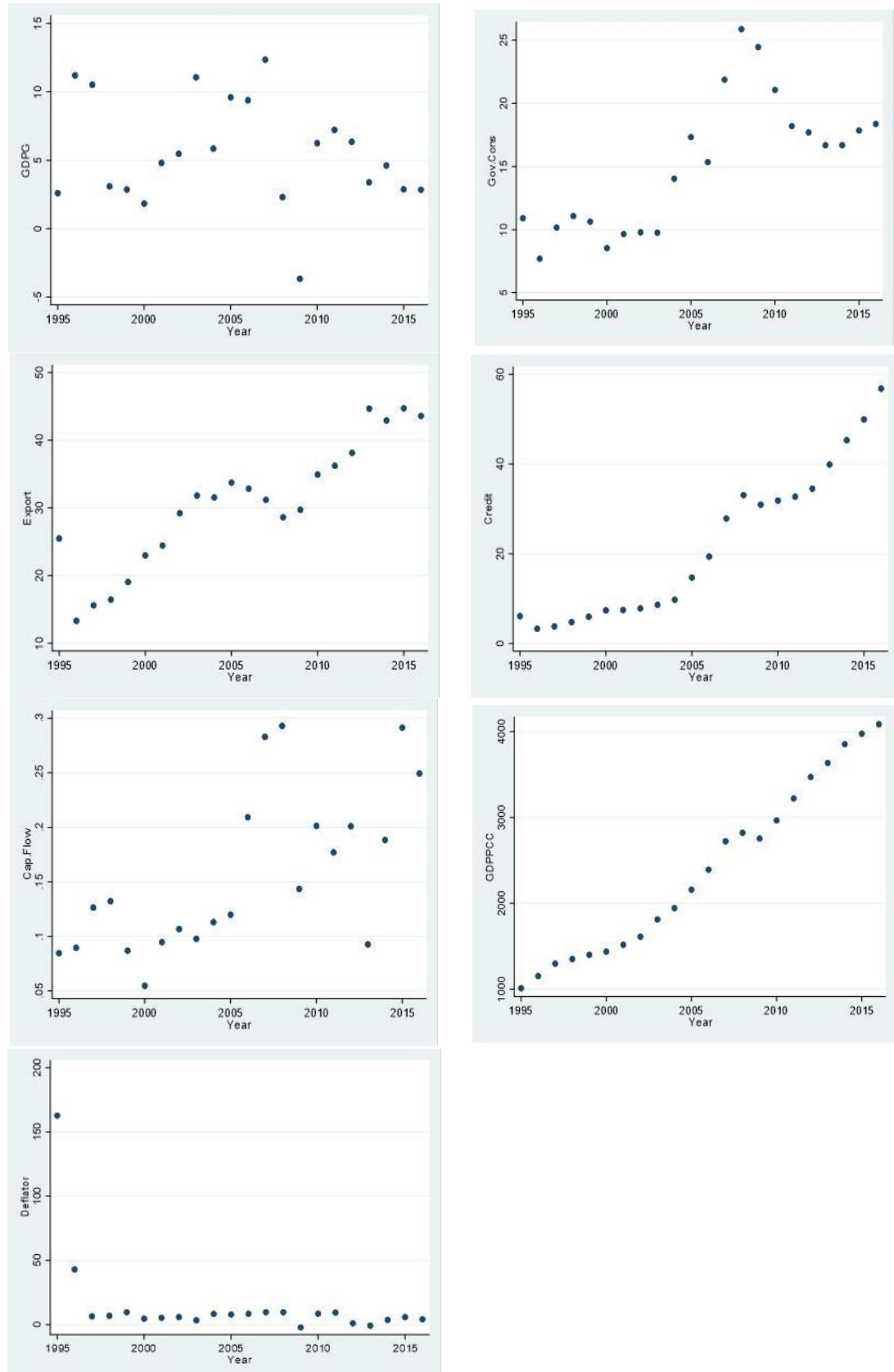

Graphs 1-7 
The solution to the problem of non-stationarity is to transform the time series data so that it becomes stationary. One way used by analysts to transform the nonstationary process into stationary process is to employ logarithm transformation method. Through this technique we create a new time series, where each value is expressed as a logarithm of its own observation. This method is widely utilized by economists in their research papers, and as a rule, it should enable us to eliminate the non-stationarity data. This means that our parameters became stationary after logarithm transformation has been applied.

\section{Empirical Results}

The major findings of the paper are reported in tables II-V, which illustrate the results of both full and sub-sample sizes. To begin with, it is essential to observe from Tables II and IV that F-tests expose to be significant at 5\% level, meaning that both models are good fit for hypothesis of interest. In addition, R2 and adjusted R2 for both sample sizes also demonstrate that the models are nicely fitted. Based on Durbin-Watson statistics there is no statistical evidence that the error terms are negatively autocorrelated, however the test is incounclusive in case of positive autocorrelation.

Table II: Financial integration and Economic growth, model summary and F-test, period covered 1995-2016

\begin{tabular}{|l|c|c|c|c|c|c|c|}
\hline Model & Sum of Squares & df & F & Sig. & R Square & Adjusted R Square & Durbin-Watson \\
\hline Regression & 229.2135 & 6 & 5.77 & $0.0049 \mathrm{~b}$ & 0.7427 & 0.6140 & 1.578565 \\
Residual & 79.4131 & 12 & & & & & \\
Total & 308.6266 & 18 & & & & & \\
\hline
\end{tabular}

Source: Own calculations via STATA

Table III: Financial integration and Economic growth, dependent variable: logarithm of GDP, period covered 1995-2016

\begin{tabular}{|l|c|c|c|c|}
\hline Model & Coef. & Std. Err. & $\mathrm{t}$ & $\mathrm{P}>\mathrm{lt}$ l \\
\hline (Constant) & -169.5945 & 50.0990 & -3.39 & 0.005 \\
LnGDPPCC & 21.8994 & 7.4841 & 2.93 & 0.013 \\
LnExport_01 & 12.4080 & 4.5029 & 2.76 & 0.017 \\
LnGovCons_01 & -0.9672 & 4.7286 & -0.20 & 0.841 \\
LnCredit_01 & -13.2542 & 3.8367 & -3.45 & 0.005 \\
LnCapFlow_01 & -1.4573 & 3.1856 & -0.46 & 0.656 \\
LnDeflator_01 & 3.0545 & 0.8093 & 3.77 & 0.003 \\
\hline
\end{tabular}

Source: Own calculations via STATA

Table IV: Financial integration and Economic growth, model summary and F-test, period covered 1995-2014

\begin{tabular}{|l|c|c|c|c|c|c|c|}
\hline Model & Sum of Squares & df & F & Sig. & R Square & Adjusted R Square & Durbin-Watson \\
\hline Regression & 240.7973 & 6 & 8.17 & $0.0022^{\mathrm{b}}$ & 0.8306 & 0.7289 & 2.085301 \\
Residual & 49.1137 & 10 & & & & & \\
Total & 289.9110 & 16 & & & & & \\
\hline
\end{tabular}

Source: Own calculations via STATA 
Table V: Financial integration and Economic growth, dependent variable: logarithm of GDP, period covered 1995-2014

\begin{tabular}{|l|c|c|c|c|}
\hline Model & Coef. & Std. Err. & $\mathrm{t}$ & $\mathrm{P}>1 \mathrm{t} \mathrm{l}$ \\
\hline (Constant) & -167.6156 & 43.2197 & -3.88 & 0.003 \\
LnGDPPCC & 22.5469 & 6.4881 & 3.48 & 0.006 \\
LnExport_01 & 12.4418 & 3.9422 & 3.16 & 0.010 \\
LnGovCons_01 & -8.9396 & 5.2073 & -1.72 & 0.117 \\
LnCredit_01 & -10.5314 & 3.4861 & -3.02 & 0.013 \\
LnCapFlow_01 & 1.0011 & 3.0479 & 0.33 & 0.749 \\
LnDeflator_01 & 3.4838 & 0.7185 & 4.85 & 0.001 \\
\hline
\end{tabular}

Source: Own calculations via STATA

The signs of the estimated coefficients are consistent with theory, although, some coefficients appear to be non-significant. Particularly, when the data incorporate periods with significant currency fluctuations (i.e. full sample size, covering years 19952016), the sign of the capital flow appears to be negative. Similar conclusions were derived by previous studies that concentrated on relationship of financial integration and currency crisis during 90s in Latin America, Asia and Russia [Stiglitz, 2000; Wang, 2006; Pinto and Ulatov, 2010]. While, on the other hand, when the data incorporate only 19952014 periods (i.e. excluding significant currency fluctuations during 2015-2016), the sign of the financial integration variable happens to be positive, as supported by various previous studies on openness theory [Lucas, 1990; Klein and Olivei, 2000; Levine, 2001; Bonfiglioli, 2008; Mahajan and Verma, 2015]. Even though the outcome of this study does not confirm the significance, it is important to note the main tendency - financial integration parameter is negative during the period of currency fluctuations and positive during relatively stable currency periods.

The results of other independent coefficients reveal that the level of GDP per capita and Exports matter for economic growth and are significant at 5\% level; additionally, inflation appears to be also in a positive and significant (at 5\%) relationship with GDP growth of Georgia. On the other hand, private credit and government consumption are adversely correlated to GDP growth, as projected by theory. Negative interrelation of GDP growth and private credit is in line with previous findings by Zhao [2016], Halil Aric [2014] and Djalilov and Piesse [2011]. Government expenditures are not significant, but they are consistent with our theory and support prior researches in this area.

As it stands, statistical significance of integration-growth relationship is not confirmed. Analyses show that financial integration has a negative influence on economic growth during the period of currency fluctuations and positive influence when such fluctuations are absent. The marginal consequences of GDP per capita, exports and inflation are empirically important indicators of GDP growth. In addition, it seems private credit and government expenditures to be negatively related to the degree of economic growth in Georgia.

\section{Conclusions}

This paper attempts to investigate the relationship between financial integration and economic growth in the Republic of Georgia. The study employs a log-linear 
equation, comprising of one dependent and six independent variables. Utilizing timeseries data over the period of 1995-2016 and using OLS estimator, the empirical investigation reveals that the statistical significance of IFI-growth relationship is not confirmed. However, although the significance of this linkage is not apparent, it is important to underline the main tendency - financial integration plays positive role when the country has relatively stable currency and negative role during the period of significant currency fluctuations. Outcomes of the study are consistent with our theory and support prior researches in this area.

The level of financial integration of Georgia into global financial system is still in its developing stages. One of the major explanations could be the fact that the country's financial industry is relatively new, because the actual development of this sector started just after the "Rose Revolution" in year 2003. Before this revolution financial sector was extremely small and unpopular among Georgian population, regional investors and international institutions.

The results of this study suggest that incentives for further expansion of the financial integration could promote economic growth in Georgia. Yet, recent currency fluctuation in years 2015-2016 showed that financial integration can bring negative consequences as well. Therefore, in order to reap only positive and avoid negative effects of financial openness, it is vital for the appropriate governmental and non-governmental organizations to develop and implement proper policies and support general institutional quality development in the country.

\section{References}

Acemoglu, D. and Zilibotti, F. (1997). Was Prometheus Unbound by Chance? Risk, Diversification, and Growth. Journal of Political Economy, 105 (4), 709-75.

Alesina, A. and Rodrik, D. (1994). Distributive Politics and Economic Growth. Quarterly Journal of Economics, 109 (2), 465- 490.

Alfaro, L., Chanda, A., Kalemli-Ozcan, S., \& Sayek, S. (2004). FDI and Economic Growth: The Role of Local Financial Markets. Journal of International Economics, 64 (1), 89-112.

Aoki, K., Benigno, G. and Kiyotaki, N. (2006). Adjusting to capital liberalization. London School of Economics and Political Science

Arteta, C., Eichengreen, B. and Wyplosz, C. (2001). Do the Effects of Capital Account Liberalization Depend on the Stage of Financial and Institutional Development? Unpublished manuscript, University of California, Berkeley, and Graduate Institute of International Studies, Geneva

Badri, A. K., Sheshgelani, A.P., (2016). Financial development, financial integration and economic growth. American Journal of Business and Society, 1(4), 195-199.

Beck, T. and Levine, R. (2004). Stock Markets, Banks, and Growth: Panel Evidence. Journal of Banking and Finance, 28(3), 423-42.

Beck, T., Asli, D.-K. \& Ouarda, M. (2013). Islamic vs. conventional banking: Business model, efficiency and stability. Journal of Banking \& Finance, 37, 433-447.

Bekaert, G., Campbell, R.H. \& Lundblad, C. (2005). Does financial liberalization spur growth? Journal of Financial Economics, 77, 3-55.

Bonfiglioli, A. (2008). Financial Integration, Productivity and Capital Accumulation. Journal of International Economics, 76, 337-355.

Boyd, J.H., Smith, B.D. (1992). Intermediation and the equilibrium allocation of investment capital: Implications for economic development. Journal of Monetary Economics, 30, 409-432.

Djalilov, K., \& Piesse, J. (2011). Financial development and growth in transition countries: A study of Central Asia. Emerging Markets Finance and Trade, 47(6), 4-23. 
Durham, J. B. (2004). Absorptive Capacity and the Effects of Foreign Direct Investment and Equity Foreign Portfolio Investment on Economic Growth. European Economic Review, 48(2), 285-306.

Edison, H. J., Levine, R., Ricci, L., \& Sløk, T. (2002). International financial integration and economic growth. Journal of International Money and Finance, 21 (6), 749-776.

Edison, H. J., Klein, M. W., Ricci, L. A. \& Slk, T. (2004). Capital Account Liberalization and Economic Performance: Survey and Synthesis. IMF Staff Papers, 51, 2.

Edwards, S. (2001). Capital Mobility and Economic Performance: Are Emerging Economies Different? Working Paper 8076, National Bureau of Economic Research.

Estrada, G.B., Park, D. \& Ramayandi, A. (2015). Financial development, financial openness, and economic growth. Technical Report 442, Asian Development Bank Economics Working Paper.

Friedrich, C., Schnabel, I. \& Zettelmeyer, J. (2010). Financial integration and growth-Is emerging Europe different? European Bank for Reconstruction and Development Working Paper.

Grilli, V. and Milesi-Ferretti, G.M. (1995). Structural Determinants and Economic Effects of Capital Controls. International Monetary Fund Staff Papers, 42(3), 54-88.

Halil Aric, K. (2014). The effects of financial development on economic growth in the European Union: a panel data analysis. International journal of economic practices and theories, 4.

International Monetary Fund (IMF). Financial Access Survey. Retrieved from https://www.imf.org/en/News/Articles/2017/10/02/pr17383-imf-releases-2017-financialaccess-survey

Ju, J. and Wei, S.-J. (2007). Domestic Institutions and the Bypass Effect of Financial Globalization. National Bureau of Economic Research. Working Paper 13148.

Khan, B. M. S. and Senhadji, A. S. (2001). Threshold Effects in the Relationship Between Inflation and Growth. IMF Staff Papers, 48, 1.

King, R. G. and Levine, R. (1993b). Finance and Growth: Schumpeter Might Be Right. The Quarterly Journal of Economics, 108(3), 717-37.

Klein, M. W. (2005). Capital Account Liberalization, Institutional Quality and Economic Growth: Theory and Evidence. Manuscript, Fletcher School of Law and Diplomacy.

Klein, M. and Olivei, G. (2000). Capital Account Liberalization, Financial Depth, and Economic Growth. (Unpublished; Tufts University)

Kose, M.A., Prasad, E.S., Terrones, M. (2008b). Does Openness to International Financial Flows Contribute to Productivity Growth? IZA Discussion Paper No. 3634.

Kose, M. A., Prasad, E. S., Terrones, M. E. (2009). Does financial globalization promote risk sharing? Journal of Development Economics, 89(2), 258-270.

Kose, M.A., Prasad, E.S., Rogoff, K., Wei, S.-J. (2010). Financial Globalization and Economic Policies. Handbook of Development Economics, 5, 4283-4359.

Kraay, A. (1998). In Search of the Macroeconomic Effects of Capital Account Liberalization. Manuscript, The World Bank.

Krugman, P. (1993). International Finance and Economic Development. Cambridge University Press, 11-24.

Lane, P. R. and Milesi-Ferretti, G. M. (2007). The External Wealth of Nations Mark II. Journal of International Economics, 73, 223-250.

Levin, R., Loyaza, N., \& Beck, T. (2000). Financial intermediation and growth: Causality and causes. Jourmal of Monenaty Economics, 46, 31-77.

Levine, R. (2001). International Financial Liberalisation and Economic Growth. Review of International Economics, 9, 688-702.

Levine, R. and Zervos, S. (1998). Stock Markets, Banks, and Economic Growth. American Economic Review, 88, $537-558$.

Lucas, R. E. (1990). Why doesn't Capital Flow from Rich to Poor Countries? American Economic Review, 80(2), 92-96.

Mahajan, N., Verma, S. (2015). International Financial Integration and Economic Growth in India: An Empirical Investigation. Eurasian Journal of Business and Economics, 8(16), 121-137.

Marin, D., (1992). Is the export-led growth hypothesis valid for industrialized countries? The Review of Economics and Statistics, 74.

McKinnon, R. (1991). The Order of Economic Liberalization: Financial Control in the Transition to a Market Economy. John Hopkins University Press. 
Mubarik, Y. A. (2005). Inflation and Growth: An Estimate of the Threshold Level of Inflation in Pakistan. State Bank of Pakistan - Research Bulletin, 1, 35-44.

National Bank of Georgia. Retrieved from https://www.nbg.gov.ge/index.php?m=2

National Statistics Office of Georgia. Retrieved from http://www.geostat.ge

Obstfeld, M. (1994). Risk-taking, global diversification and growth. American Economic Review, 85, 1310-1329.

Obstfeld, M. (2008). International Finance and Growth in Developing Countries: What Have We Learned? Commission on Growth and Development, Working Paper,34.

Pinto, B. and Ulatov, S. (2010). Financial Globalization and the Russian Crisis of 1998. Elsevier Encyclopedia of Financial Globalization.

Prasad, E.S., Rajan, R.G. and Subramanian, A. (2006). Patterns of International Capital Flows and their Implications for Economic Development. Federal Reserve Bank of Kansas, Jackson Hole Conference Paper, 119158.

Prasanna, S. \& Gopakumar, K.(2011). An Empirical Analysis of Inflation and Economic Growth in India. International Journal of Sustainable Development, 15(2), 4-5

Quinn, D. (1977). The Correlates of Change in International Financial Regulation. American Political Science Review, 91, 531-51.

Quinn, D., Schindler, M. and Toyoda, A.-M. (2011). Assessing measures of financial openness and integration. IMF Economic Review, 59(3), 488-522.

Rajan, R., Zingales, L.(2003). The great reversals: the politics of financial development in the twentieth century. Journal of Financial Economics, 69, 5-50.

Rodrik, D. and Subramanian, A. (2008). Why Did Financial Globalization Disappoint? IMF Staff Papers, 56, $112-138$.

Rodrik, D. (1998). Why Do More Open Economies Have Bigger Governments? Journal of Political Economy.

Sarel, M. (1996). Nonlinear Effects of Inflation on Economic Growth. IMF Working papers, 95/56.

Skipper, H.D., Kwon, W.J. (2007). Risk Management and Insurance: Perspectives in a Global Economy. Boston: John Wiley-Blackwell Publishing, 290.

Stiglitz, J. (2000). Capital Market Liberalization, Economic Growth, and Instability. World Development, 28(6), 1075-1086.

Vohra, R., (2001). Export and Economic Growth: Further Time Series Evidence from Less Developed Countries. International Advances in Economic Research, 7.

Wang, J-Y. (2006). Financial Liberalization in East Asia: Lessons from Financial Crises and the Chinese Experience of Controlled Liberalization. Journal of World Trade.

Webb, I., Grace, M.F. and Skipper, H. D. (2002). The Effect of Banking and Insurance on the Growth of Capital and Output. Center for Risk Management and Insurance. Working Paper, 02.

World Development Indicators Database. Retrieved from https://data.worldbank.org/products/wdi

Zhao, S. (2016). Does Financial Development necessarily lead to economic growth? Evidence from China's cities, 20072014. School of Business, Macau University of Science and Technology. 